\title{
O "COLETIVO" COMO ESTRATÉGIA TERRITORIAL DOS CATIVOS
}

\author{
HUGO FREITAS DOS SANTOS \\ Doutorando do Programa de Pós-Graduação em Geografia \\ Universidade Federal Fluminense
}

Ao examinar os "coletivos" como estratégia territorial dos internos prisionais, nos prevaleceu o sentimento de que a prisão não recupera, mas degenera. Limpa ou imunda, transbordada de pessoas ou adequadamente ocupada, próxima ou distante, pública ou privada, a prisão é vista como um mal, muitas vezes inútil. Com efeito, não há quem aponte, hoje, algum aspecto positivo do cárcere relacionado ao desenvolvimento humano'. A análise do espaço prisional deve constituir as bases psicológicas e materiais que são formadas nas instituições do cárcere. Os alicerces estratégicos das prisões são diversificados em termos de arquitetura, de figuras espaciais que permitem o controle da sociedade cativa. Se vasculharmos a hipótese de Nietzsche, veremos que as relações de poder sempre estão em potência nas instituições prisionais: ataque (repressão) e defesa (conservação) são as artimanhas de uma guerra que estabelece a obsessão pelo controle dos territórios.

A proeminência da prisão é um caso extremo ligado à desterritorialização. Os procedimentos de "i-mobilidade" (imobilização e reclusão) produzem a percepção de conduta, regulação e opreșsão dos usuários dos territórios prisionais; os internos não têm o efetivo controle ou a identificação com este espaço (HAESBAERT, 2004:251-263). Sendo o território um conceito geográfico amplamente discutido e freqüentemente abordado sob diferentes perspectivas, seja referenciando a política, a economia ou a cultura, o território pode, ao mesmo tempo, acolher uma acepção integradora entre estas dimensões. Assim como para

\footnotetext{
' A prisão é, na fina ironia de Foucault (1991:208), a "detestável solução, de que não se pode abrir mão. (...) A prisão é 'natural' como é 'natural' na nossa sociedade o uso do tempo para medir as trocas".
} 
o território, temos também uma diversidade de concepções para territorialidade, territorialização, desterritorialização e reterritorialização-conceitos diretamente atrelados ao território².

Para a análise do "coletivo" prisional, a visão integradora nos parece vital, pois descreve os processos territorializadores por meio das relações sociais de poder e do controle do espaço. $\mathrm{Na}$ abordagem integradora; o território só pode ser imaginado na interseção entre as diferentes dimensões sociais e "controle do/pelo espaço, relações de poder em sentido amplo, ao mesmo tempo de forma mais concreta (dominação) e mais simbólica (um tipo de apropriação)" (HAESBAERT, 2004:235). Desenvolvendo o aspecto relacional, Souza (1995:86-7) explica que os territórios "são no fundo antes relações sociais projetadas no espaço que espaços concretos"; pressupõe que a abordagem territorial não deve ser descolada das dimensões políticas e culturais da sociedade. O território será um campo de forças, uma teia ou rede de relações sociais que define uma alteridade: a diferença entre os insiders (o grupo, os membros da coletividade ou comunidade) e os outsiders (os "de fora", os estranhos).

Seguindo este propósito, Raffestin (1993) indica que o território demarca um circuito conceitual análogo ao poder, abalizando valores territorializantes ligados à tecnologia, à informação e à semiologia, destacando-se não apenas as circunscrições e os controles, mas sobretudo o atributo dos fluxos e das redes. Raffestin reivindica o território como uma área de relações de poder (o "campo do poder"), ligando as formações territoriais ao controle de acesso de uma determinada área, seja para desfrutar dos recursos ou para controlar os fluxos de pessoas e de bens: "o poder visa o controle e a dominação sobre os homens e sobre as coisas" (p.50). Para Raffestin, o espaço é preexistente ao território, constituindo-se como um dado preestabelecido, ou seja, um a priori: "O espaço é a 'prisão original', o território é a prisão que os homens constroem para si. (...) O espaço é, portanto, anterior e preexistente a qualquer ação. O espaço é, de certa forma, 'dado' como se fosse uma matéria-bruta. Preexiste a qualquer ação" (p.144). Logo, o território é uma produção no espaço, sendo o "resultado de uma ação conduzida por um ator sintagmático (ator que realiza um programa) em qualquer nível. Ao se apropriar de um espaço, de forma concreta ou abstratamente (por exemplo, pela representação), o ator 'territorializa' o espaço" (p.143).

Definido como um recorte espacial, o território se arquiteta através das relações de poder com vistas à dominação de áreas ou zonas, demarcadas através

\footnotetext{
${ }^{2}$ Claude Raffestin, dedicando-se ao conceito do território, analisa o processo denominado T-D-R, ou seja, através de um conjunto de conceitos atrelados: territorialização-desterritorializaçãoreterritorialização. "Para ele [Raffestin] a territorialidade humana (...) 'pode ser definida como o conjunto de relações que desenvolve uma coletividade $-e$, portanto, um indivíduo que a ela pertence - com a exterioridade e/ou a alteridade por meio de mediadores ou instrumentos" (HAESBAERT, 1997:32).
} 
de limites (ou fronteiras), formando o lugar onde estas relações de poder se dão, ou seja, a "cena do poder": "o poder é imanente a toda relação que é o teatro e o lugar do confronto" (p.50). Poderíamos dizer, então, que o território é o local de relações edificado no espaço por um poder concebido e estabelecido; o espaço e o tempo seriam os trunfos (suportes) que, através das relações de poder, condicionam a existência dos territórios (o campo da ação dos trunfos) (pp.58-60). A conexão população-território-recursos constitui a problemática relacional do "campo do poder".

Com esta análise do território desenvolvida por Raffestin, fundamentada nas idéias de Foucault ${ }^{3}$, podemos entender que os territórios prisionais têm no poder e no saber a sua base disciplinar. No jogo do poder deve-se ter em mãos o conhecimento e a prática, artifícios para o domínio territorial; deve-se ter o conhecimento para o poder ser representado, para se ter o planejamento, o modo de apropriação e a ciência de uso; precisa ser praticado porque se constitui como poder materializado no espaço, exercido pela intencionalidade de uma experiência integral e indivisível. Pedro Fraile (1990) nos dirá que o poder "está em todo lugar porque nasce da própria desigualdade das partes e de sua relação mútua". Tendo o poder qualidades que o tornam o instrumento de controle social por excelência, para colocá-lo em prática faz-se necessário um saber, "uma técnica que firme atuações, crie formas, distribua pessoas e organize o território" (pp.18-21). Já Sánchez (1990) nos mostra que "toda ação social requer uma base territorial (...). As relações de poder guiarão a articulação social do espaço. (...) só é possível entender as relações de poder em sua configuração integradora da sociedade" (p.83). Portanto, o território deve ser entendido como o instrumento de exercício do poder materializado no espaço, requerendo um constante empenho de demonstração e utilização do poder e de suas estratégias para seu estabelecimento e manutenção. As noções de território e territorialidade são limitadas espacialmente, vistas tanto no sentido da dominação quanto no da resistência do dominado. De tal modo, a luta territorial e o domínio do espaço prisional serão sempre construídos pela ação de seus partícipes:

\footnotetext{
${ }^{3}$ A relação teórica entre Raffestin e Foucault foi analisada por Haesbaert (2004:83-84): "Poderíamos enfatizar as características foucaultianas de que o poder não é um objeto ou coisa, mas uma relação, e que esta relação, ainda que desigual, não tem um "centro" unitário de onde emana o poder (como o Estado em algumas posições marxistas mais ortodoxas). (...) Baseada nesta leitura de poder, a concep̧̧ão de território em Raffestin torna-se bastante ampla, o território como a 'prisão' que os homens constroem para si, ou melhor, o espaço socialmente apropriado, produzido, dotado de significado. A idéia de controle do espaço está bastante evidente através do termo "prisão", mas a territorialidade não se restringe a um conjunto de relações de poder, ou melhor, a noção de poder de Raffestin é suficientemente ampla para incluir também a própria natureza econômica e simbólica do poder".
} 
A territorialidade aparece (...) como constituída de relações mediatizadas, simétricas ou dissimétricas com a exterioridade. (...) A territorialidade se inscreve no quadro da produção, da troca e do consumo das coisas. Conceber a territorialidade como uma simples ligação com o espaço seria fazer renascer um determinismo sem interesse. É sempre uma relação, mesmo que dijerenciada, com outros atores (RAFFESTIN, 1993:161).

Assim, as territorialidades desenvolvidas nas prisões são "portáteis", pois permitem reconstituir novos horizontes e anseios no espaço prisional quando novos territórios são apropriados, possibilitando deslocamentos no interior ou fora do espaço prisional, recompondo reterritorializações. A territorialidade prisional poderá ser, também, uma fonte ou um apoio a hostilidades, exclusões e ódios. Na sociedade dos cativos, a formação do "coletivo" foi causada pelo agrave dos problemas ligados à superpopulação, à frustração dos internos estarem desterritorializados, abandonados e revoltados com o sistema prisional.

Sendo o "coletivo" uma estratégia de ação territorial formada nos presídios em que estão distribuídos os elementos da facção criminosa Comando Vermelho (primeiro grupo organizado de presos no país, extremamente politizado), devemos nos remeter ao passado, ou seja, ao momento das conquistas territoriais do crime organizado para compreendê-lo. O crime organizado surgiu no Brasil nos porões do extinto Presídio Cândido Mendes (Ilha Grande), mais especificamente na Galeria B, conhecida como "Fundão". O Comando Vermelho veio ao mundo na década de 1970 como uma corrente de solidariedade carcerária, em função da inspiração do ideal coletivo implantado pelos presos políticos da ditadura militar na mentalidade da sociedade cativa da Ilha Grande, ao longo de seu fluxo genealógico. Este é um dos aspectos da gênese do Comando Vermelho. Conforme as palavras de Costa e Vieira (2004:9):

não podemos esquecer que antes existia o mito, o simbolismo, do "malandro carioca" que era uma espécie de "Robin Hood" tropical e negro que, na favela, conheceu a experiência solidária da "malta de capoeira". Este malandro ideal acumula também a história da desilusão dos soldados negros egressos da guerra do Paraguai e a transformação da favela em um quilombo moderno imaginário como refúgio dos pobres. (...) Por outro lado, os malandros "donos dos morros" - que até então não eram traficantes - conheceram nas prisões cariocas as lideranças $e$ os militantes das Ligas Camponesas que eram transferidos do interior do Brasil para as prisões do Rio. Este foi um primeiro contato com os presos políticos. Depois, em função do continuo fluxo de presos políticos - na sua maioria comunistas e também anarquistas - desenvolveram relações de convivência, mas também de aberta comunicação. 
Em 1969, a junta de ministros militares, que substituiu temporariamente o presidente-general Costa e Silva, iniciou o processo de endurecimento do regime militar no Brasil. O governo repressor, tentando disponibilizar as ações dos setores de esquerda que enveredaram na luta armada desde 1967, estrategicamente tratou a resistência dos guerrilheiros pelo viés do banditismo. Ambicionando nivelar o militante ao "bandido comum" - o que permitia uma boa argumentação para enfrentar as pressões internacionais em prol da anistia e contra as denúncias de tortura - mal sabiam os militares que, desta conjugação, surgiria uma perigosa experiência da organização dos presos ${ }^{4}$ : o Comando Vermelho (CV). Por iniciativa da junta dos ministros militares, foi aprovada em caráter de urgência a regulamentação da Lei de Segurança Nacional (LSN). O Artigo 27 do DecretoLei 898 agravava as penas para assalto, roubo e depredação nas instituições financeiras e de crédito. Estes crimes deixaram de ser julgados pelo Código de Processo Penal e passaram para o âmbito dos tribunais militares. As auditorias das "três armas" viram desfilar os mais variados tipos de criminosos comuns. Estes bandidos seriam julgados pelos mesmos "crimes" cometidos pelas organizações da esquerda armada. Gente conhecida nos noticiários de jornais e televisões Escadinha, Rogério Lengruber (o "Bagulhão"), Zé do Bigode e dezenas de personagens do submundo do crime - enfrentou o Conselho de Sentença. As penas, aumentadas pela LSN, iam de 10 a 24 anos de prisão. O parágrafo único do Artigo 27 estabelecia ainda que: "Se dessas acusações resultar a morte de alguém, a pena em grau mínimo será de prisão perpétua e, em grau máximo, a pena de morte".

Cândido Mendes, presídio de muitos horrores e o mais pobre de todo o sistema carcerário do estado do Rio de Janeiro, era a passagem para os condenados da LSN. A cadeia, construída para abrigar 540 presos, sempre esteve superlotada, ultrapassando nos anos de 1970 o número de 1.200 internos. Os problemas deste presídio eram os mesmos dos presídios de hoje: superlotação e falta de comida, de colchões, de uniformes para os presos, de cobertores, de remédios etc. Na Ilha Grande, lutava-se até por um prato extra de comida; disputava-se a facadas um maço de cigarros ou uma "bagana" de maconha; cocaína e armas de fogo podiam ser razões para um motim; comprava-se e vendia-se "moças" (homossexuais

\footnotetext{
${ }^{4}$ A convivência entre presos políticos e criminosos "comuns" já era algo costumeiro na história da República brasileira, embora esta convivência estivesse suspensa no Rio de Janeiro entre 1946 e 1964. A experiência integradora desta convivência foi reativada com a rebelião dos marinheiros que ocuparam o Sindicato dos Metalúrgicos na rua Ana Nery. "O movimento foi um dos estopins do golpe que derrubou o presidente João Goulart. A justiça militar considerou o caso uma transgressão disciplinar, punindo de sessenta a oitenta marinheiros com base no código penal das Forças Armadas, que estabelece: 'Os condenados devem cumprir sentença nos estabelecimentos penais comuns, submetidos ao regime do estabelecimento"' (AMORIM, 2003:82). Por tanto, a experiência que veremos - a da Lei de Segurança Nacional (1969) - não foi a primeira experiência desse tipo. A convivência entre militantes de esquerda e criminosos já ocorria ao longo da história republicana, inicialmente com a influência anarquista e, depois, com a comunista.
} 
subjugados pela força) como mercadorias de câmbio bastante valorizado (AMORIM, 2003:50). Na Ilha Grande, a territorialidade dos presos se constituía, sobretudo, em bando. Os grupos de presos - as famosas "falanges" as quatro galerias do presídio, cuja distribuição dos internos era feita de acordo com o local de origem. Seis quadrilhas se enfrentavam pelo domínio territorial do Cândido Mendes. Cada grupo tinha uma estratégia própria, um código interno de leis, normas de conduta e outros modelos de identificação. A divisão territorial das falanges no "campo do poder" prisional da ilha se constituía da seguinte forma:

- Falange Zona Norte: também conhecida como Falange do Jacaré, seu território era a Galeria D, a mais temida do presídio. Era formada pelos criminosos que habitavam as favelas e bairros proletários de Del Castilho, Benfica, Jacaré e Bonsucesso. Tais delinqüentes mantinham uma relação de autodefesa através de um forte sentimento de gangue, controlando cerca de duzentos homens; eram os bandidos mais perigosos da Ilha Grande por fazerem complô junto à administração prisional, possuindo as maiores regalias. Impunham o terror prisional a bordo da ilha; cobravam pedágios, roubavam, traficavam, matavam e estupravam. A territorialidade do grupo se estendia por quase todo presídio, informalmente aceito pela administração. Tinham diversas vantagens em relação às outras falanges do presídio, como trabalho externo, o direito de circular fora dos muros, o controle da distribuição da comida e a facilidade de assaltar os mais fracos.

- Falange Zona Sul: seu território era a Galeria C, dividida com a Falange da Coréia. Era um grupo formado sob a liderança de dez homens. Sua especialidade era o jogo e o tráfico de drogas. Seu círculo de influência na Ilha Grande continha cem presos aproximadamente, onde todos colaboravam com a administração na manutenção das instalações e serviços da cadeia.

- Falange da Coréia: dividia o território da Galeria C com os custodiados da Zona Sul. Sua territorialidade abarcava apenas uma restrita parte da galeria. Era uma das falanges menos articuladas do presídio, embora conseguisse liderar uma gangue com mais de cem presos. A quadrilha tinha algum tráfico de influência junto aos guardas, facilitando a vida de seus colaboradores e aliados (a Falange do Jacaré). Seus "falangistas" tinham como principais características a prática da violência sexual e o ataque para roubar outros presos. Quando deflagrada a guerra que vai dar a hegemonia do presídio ao Comando Vermelho, os dois grupos da Galeria $\mathrm{C}$ se unem e formam a facção criminosa Terceiro Comando.

- Falange Vermelha: o território da Falange Vermelha (embrião do Comando Vermelho) era o fundo da Galeria B. Por isso a falange também era conhecida como grupo do "fundão", por estarem praticamente incomunicáveis, quase sem contato com os outros detentos da ilha. Eram os únicos inimigos

\footnotetext{
${ }^{5}$ Termo explicado por William da Silva Lima, o "Professor": "Na prisão, 'falange' quer dizer um grupo de presos organizados em torno de qualquer interesse comum. Daí o apelido de 'falange LSN', logo transformada pela imprensa em 'Comando Vermelho"” (LIMA, 1991:83).
} 
declarados da Falange do Jacaré. O grupo era formado pelos presos "comuns" condenados pela Lei de Segurança Nacional (LSN). Sob a orientação de alguns presos que tiveram a vida carcerária influenciada pelos condenados de origem política, os "falangistas" formavam um grupo diferenciado na cadeia, mantendo as características das estruturas de militância advindas da luta armada. Sua organização era bastante complexa, tendo secretários, dirigentes, tarefas internas e obrigações políticas; a idéia era reproduzir dentro do presídio a estrutura da tradição guerrilheira. Com algumas divergências entre os presos "comuns" e os presos políticos, a galeria foi dividida por uma fronteira (um muro de ferro). Embora a massa carcerária do presídio tenha ficado desconfiada, estranhando os "bacanas" (como eram conhecidos os militantes de esquerda), pois o sistema apostava num conflito que poderia ocorrer, alguns militantes fizeram valer a força do carisma, impondo currículos impressionantes como "crimes de homem", violência armada e seqüestros. Aos poucos, foram ganhando um certo respeito. A influência da estrutura coletiva da guerrilha urbana determinará a estrutura da organização dos "vermelhos". É fato concreto que a união dos presos pela ideologia coletiva dava certas vantagens no jogo da vida cativa. Nascia na Ilha Grande um novo estado de espírito entre a massa carcerária na reação contra o terror sustentado pelos "jacarés".

- "Neutros" ou "Independentes": a territorialidade dos "neutros" era aparente, porque esse "grupo" era uma força de apoio da Falange do Jacaré. Tinham a atuação reconhecida por mais de duzentos presidiários da Ilha Grande, sendo onze o número de sentenciados distinguidos como "independentes" (os mais afamados eram o sindicalista Giovani Szabo e o capitão Nelson Salmon). Os "neutros" não reconheciam sua dependência perante os outros grupos, mas eram completamente individualistas e tinham uma boa reputação na cadeia. A territorialidade dos "neutros" era singular, justamente porque não viviam em bando; viviam espalhados pelas Galerias $\mathrm{C}$ e $\mathrm{D}$.

Esta era a configuração territorial das quadrilhas do presídio Cândido Mendes. Se havia algum tipo de aliança entre as falanges, esta era feita de forma autoritária, com constantes ameaças e abusos de extrema violência. A guerra promovida entre as falanges em 1979 veio para acabar com os excessos dos presos liderados pelo "jacaré". Era preciso dominar os territórios do cárcere para acabar com a "polarização" do sistema prisional, ou seja, dar fim à violência das "falanges" e à rotina agressiva do sistema penitenciário. O surgimento do "coletivo" reterritorializou os "vermelhos", iniciando uma nova configuração territorial das prisões com a inserção do crime organizado na esfera do "campo do poder" prisional. A consciência coletiva é um fenômeno ideológico que contaminou a mentalidade dos presos "comuns" da Galeria B; apreendida com os militantes de esquerda, é o conhecimento de luta e de resistência que irá sobressair, não somente em relação à inclusão da estrutura coletiva (obrigações políticas, secretarias, dirigência, tarefas internas...), como também ao aparecimento das técnicas da luta 
armada para os "presos comuns" (seqüestros e assaltos milionários bem elaborados).

Os presos do "fundão" começaram a planejar cuidadosamente suas ações fora dos presídios, a exemplo da guerrilha urbana, incorporando ao fluxo prisional os crimes na sociedade. Devemos compreender que foi assim que o crime acionou a formação de uma rede de "aparelhos" ou "paióis", alugando ou comprando casas em vários pontos que serviriam de depósito de material (armas, drogas, dinheiro...) e de resguardo para os integrantes da quadrilha organizada ("aparelhos"). Era preciso, além disso, agenciar as informações dentro e fora dos presídios nos moldes da guerrilha urbana: o "correio" é a ligação do fluxo de informações que vêm do "mundo exterior" (feito por familiares, amigos ou advogados), para a comunicação entre os próprios internos e reivindicações com a direção e o sistema. A leitura de livros e textos revolucionários afetou a mentalidade do "coletivo vermelho" com ensinamentos básicos para operações militares de pequenos grupos guerrilheiros; enquanto os presos comuns traficavam drogas, os presos políticos traficavam papéis e informações ${ }^{6}$.

No final de 1974, o "fundão" abrigava 120 condenados, tendo em 90 o número de presos "comuns" e em 30 o número de presos políticos. Os militantes aprisionados procuravam diferenciar-se da massa carcerária em geral, pois era fundamental demonstrar que constituíam um grupo à parte. Presos políticos e presos "comuns" viveram diversos momentos de tensão, daí a importância da organização do coletivo como fator diferencial, pois a ineficiência da barbárie selava as constantes derrotas dos presos desunidos. Segundo Costa e Vieira (2004:9-10), "a guerra de facções alimentava a divisão entre os presos, dando à instituição o pleno controle do complexo carcerário que nestas condições não se rebelava e tampouco conseguiu organizar fugas". Quando o efeito da estratégia coletiva sobressaiu, um grupo de oito presos se territorializou no "fundão", ostentando uma territorialidade distinta das outras. O grupo embrionário dos "vermelhos" era bastante coeso, movendo-se numa "fé cega" de resistência e ódio. Impelidos no princípio de

"As principais leituras revolucionárias apreendidas pelos presos do "fundão" eram: $O$ pequeno manual do guerrilheiro urbano (Carlos Merighela), Revolução na revolução? (Régis Debray), $O$ Manifesto do Partido Comunista (Marx e Engels), A concepção materialista da história (Afanassiev), A história da riqueza do homem (Léo Hubberman) e a Guerra de guerrilhas (Che Guevara). Este último livro destacava a importância da articulação de uma rede de abastecimento e informações; enfatizava a importância do contato com o mundo exterior (fora das zonas de combate) como fator decisivo de sobrevivência (AMORIM, 2003:92-93).

${ }^{7}$ Os integrantes da primeira "tropa de choque" da Falange Vermelha tinham uma folha penal espantosa. A lista é pública e tinha a seguinte ordem de importância, de acordo com a pesquisa de Carlos Amorim (2003:103-106): 1) William da Silva Lima, o Professor (especialista em formação de quadrilhas e assalto a bancos; único "vermelho" original ainda vivo, está preso até hoje, mas fora do crime); 2) Carlos Alberto Mesquita, também conhecido como Professor (organizador de 
responder à violência das falanges rivais, embora estivessem restritos aos limites do território de sua parte da galeria pelo isolamento, passaram de "alunos" a "professores"'. A convivência passava a ter a solidariedade como sua maior proposta, já que a cooperação entre os coletivos da Galeria B teve o seu desfecho em negociação, pois os integrantes das organizações armadas não se misturavam e rompiam ${ }^{8}$.

Finda a cooperação entre os dois coletivos da Galeria B, a Falange Vermelha se estrutura no território prisional insular definindo a sua primeira palavra de ordem: "O inimigo está fora das celas. Aqui dentro somos todos irmãos e companheiros" (AMORIM, 2003:106). A partir de então, ficava proibido no território do "fundão" o desrespeito ao "companheiro", cujo castigo era a sentença de morte. Em meados de 1975, já era notório o alcance territorial dos "vermelhos" no "campo do poder" da Ilha Grande. A Falange do Jacaré já estava de sobreaviso: a guerra fatal é uma questão de tempo.

Para os presos políticos, o caminho da anistia já era evidente com a transferência gradual para outros presídios. Se a anistia para estes parecia estar próxima, para os delinqüentes comuns só restaria o caminho de organizar seu "coletivo" contra as falanges rivais. Presos comuns não têm anistia, e os "vermelhos" sabiam disso. A comissão que procuraria negociar com os presos políticos estava na "ativa", tornando-se "comissão dirigente". Os "vermelhos" aventuraram-se, também, em agenciar com o pessoal do Desipe (essa comissão foi o primeiro secretariado de presos comuns de que se tem notícia na história do Brasil). As reivindicações, sempre definidas em conjunto, diferenciavam-se das queixas das demais falanges: enquanto as outras quadrilhas organizavam-se em torno de seus próprios interesses - e geralmente pelo terror - o grupo do "fundão" se esforçava para melhorar as condições carcerárias e reprimia o crime entre os

grandes escapadas da Ilha Grande); 3) Paulo Nunes Filho, o Careca (sua ficha criminal é pouco informativa; foi condenado por assalto a banco); 4) Paulo Cezar Chaves, o PC Branco (redator oficial dos documentos do Comando Vermelho; definia as reivindicações da falange); 5) José Jorge Saldanha, o Zé do Bigode (era o mais apaixonado pela idéia de organizar os presos da LSN e neutralizar o poder das falanges inimigas); 6) Eucanan de Azevedo, o Canã (fez carreira no crime, enfrentando os tribunais treze vezes acusado de roubo); 7) Iassy de Castro, o Iacy (assaltante e assassino perigoso); e 8) Apolinário de Souza, o Nanai (organizador de resgates de presos da ilha; organizava a batucada e cantava sambas famosos, além de pregar a Bíblia entre os condenados com um enfoque de salvação social, quase revolucionário).

${ }^{8}$ Sobre o rompimento dos "coletivos" da Galeria B, nos disse William da Silva Lima: “(...) não tive êxito. Terminara o período de cooperação entre os dois coletivos. 'Existem 30 presos políticos na Ilha Grande', escreviam em seus documentos. 'Somos 90 presos proletários', respondíamos, com uma ponta de mágoa e provocação. Éramos testemunhas que as gerações anteriores de ativistas políticos tinham feito questão de conviver com a massa, da qual sentiam-se parte e pela qual desejavam zelar. Dessa vez, as condições eram ainda mais favoráveis: tínhamos a experiência de outros contatos, estávamos organizados (...). Mas eles não perceberam - ou não quiseram perceber - a oportunidade de convivência" (LIMA, 1991:48-9). 
próprios criminosos.

Neste mesmo ano (1975), um encontro do "coletivo vermelho" com as autoridades públicas para discutir as reivindicações (dentre as quais o fim dos espancamentos, a liberdade de circular pela galeria e melhor tratamento para as visitas) deu um novo status ao "fundão", acompanhado por um tenso suspense. $\mathrm{O}$ rebate às reivindicações foi em tom de ameaça, pois o grupo seria dividido pelas demais galerias, fato que poderia resultar num banho de sangue. Mas os "vermelhos" encararam os agentes de frente, recusando a aceitar as transferências. Para desmoralizar o "território vermelho", surge uma discrepância de conseqüências trágicas: dias depois do encontro com os porta-vozes do governo, uma briga dentro de uma cela $\mathrm{LSN}^{*}$ termina com a morte de um presidiário. Para os fundadores do CV foi um tipo de traição imperdoável. O responsável pelo assassinato foi condenado pelo "coletivo" à morte e executado a golpes de estoques (armas improvisadas de perfuração). Na cadeia, é vencer ou morrer sempre.

Aos poucos, entre 1975 e 1977, o núcleo principal da Falange Vermelha vai sendo ampliado de 8 para 31 homens. Reuniões, tarefas e conscientização são as bases de uma organização que se imprime ao movimento. Os novos integrantes eram todos criminosos de alta periculosidade". Certamente, "ali não havia inocentes, gente que não tivesse feito por merecer cadeia dura. Na psicologia particularíssima do crime, isto é motivo de orgulho - e não de autopiedade. Aqui vale a máxima 'quanto pior melhor', desde que seja leal com os companheiros e fiel ao código de conduta" (Amorim, 2003:111). Até 1979, o "território vermelho" limitava-se aos muros do Instituto Penal Cândido Mendes, afirmando os princípios de organizar para sobreviver, unir para resistir.

Em 28 de agosto desse ano, os juristas a serviço do governo militar formulam o Decreto-Lei 6.683, sancionando a anistia geral. Enquanto os presos "comuns" viam os presos políticos indo embora, pois todos os delitos relacionados com a luta política foram perdoados, uma ressalva excetuava a anistia pela prática de crimes de terrorismo, assalto, sequiestro e atentado pessoal. A resistência do pessoal do "fundão" continuaria firme, porque agora o regime militar promovia o oposto de antes, ou seja, diferenciava o bandido comum do militante revolucionário: “(...) aos presos políticos foi dada a anistia, enquanto nós fomos lentamente

\footnotetext{
* Cela dos presos custodiados pela Lei de Segurança Nacional (LSN), conforme discutido anteriormente.

${ }^{9}$ Dentre as novas cartas do baralho, destacaremos as mais conhecidas: Júlio Augusto Diegues, o Portuguesinho (veterano assaltante de bancos; integrou o bando do famoso bandido Lúcio Flávio); Expedito Rafael da Silva (gerente dos negócios da organização dentro da Ilha Grande); Francisco Viriato de Oliveira, o Japonês (terrível criminoso, até 1996 foi um dos chefões do CV); Silvio de Carvalho, o Silvio Maldição (especialista em roubar carros-fortes e bancos); Rogério Lengruber, o Bagulhão (traficante de drogas e famoso dirigente do CV; gostava de denominar-se Marechal); Paulo da Cunha Franco (veterano de fugas extraordinárias).
} 
aniquilados" (LIMA, 1991:59). Com a "absolvição" dos militantes, o governo não via mais a necessidade de isolar os presos do "fundão", que deixava de ser um território escondido atrás dos portões de ferro da Galeria B. A Falange Vermelha ganhava o acesso ao pátio coletivo com a abertura das celas, ampliando a ideologia coletiva do grupo em territórios antes proibidos.

A hegemonia territorial da penitenciária da Itha Grande pela Falange Vermelha se concretiza seguida de um novo código de comportamento dentro das prisões: "A Disciplina". Modificando as relações entre os presos, a "Disciplina" alastrava os princípios de coletividade e moralizava as ações do grupo do "fundão". Com o convencimento ou mesmo impondo a sua força através da coerção física, os "vermelhos" conseguiram dominar as outras falanges e impor um novo comportamento no presídio. $O$ "coletivo" buscou o recrutamento e a ampliação de sua influência no espaço carcerário através de iniciativas práticas, sobretudo com a fundação e o controle do Clube Cultural e Recreativo do Interno (CCRI), conquistando mudanças antes nunca imaginadas para o conjunto dos presos da Ilha Grande: a administração da cantina, a adoção dos mais velhos, a coordenação da farmácia, a circulação de um jornal ("O Colonial"), o surgimento de uma biblioteca e a criação de um time de futebol dos internos (o "Chora na Cruz"). Com as melhorias, a massa carcerária começou a ser conquistada pela Falange Vermelha, ganhando novas adesões e fortalecendo a organização do "coletivo" para a disputa territorial contra a Falange do Jacaré ${ }^{10}$.

A reação dos inimigos da Falange Vermelha contra a expansão de sua territorialidade será imediata. O pacto de conduta da organização, que não permitia assaltos e violências, seria corrompido a qualquer momento pelas falanges rivais. Num ritmo febril, todas as falanges preparavam-se para o confronto direto, arranjando todo tipo de arsenal improvisado. Um ultimato dos "vermelhos" foi dado às falanges rivais: a adoção das regras da organização ou a eliminação. Do outro lado, a Falange Zona Norte opta pela prudência e anuncia o isolamento de sua galeria, ficando presa numa armadilha. Acabado o prazo dado pelos "vermelhos" para a rendição da Falange Jacaré, o cubículo número 24 da Galeria $\mathrm{C}$, distante da entrada do corredor, acolhe as lideranças inimigas. No raiar do dia 17 de setembro de 1979, a Falange Vermelha invade o território hostil com dezenas de presos armados. A tensão é grande; a batalha é rápida, sangrenta, implacável; os inimigos são mortos a golpes de estoques, socos e pontapés. No massacre, as

\footnotetext{
${ }^{10}$ Segundo Pereira (1994:41), "a população carcerária foi doutrinada pelos presos políticos da LSN para criarem um centro recreativo, conforme modelo da Ilha Grande, adotando a sigla CCRI. Esses centros eram equipados com mesas de sinuca, aparelhos de TV a cores, equipamentos de som sofisticado, conjunto de bateria completo e rádio com transmissor (...), captando informações da cadeia a Direção Geral. (...) Os presos comuns, envolvidos em assaltos a banco, foram os embriões do Comando Vermelho. Controlavam no Cândido Mendes o centro recreativo, a federação de futebol (também criada por eles) e desenvolviam (...) cursos de alfabetização e primeiro grau".
} 
lideranças da Falange Jacaré ficam desterritorializadas, despedaçadas. A cela é invadida e outros presos são feridos ou mortos; alguns conseguem fugir. A carnificina "marca a tomada do poder pelo Comando Vermelho na Ilha Grande. Os grupos menores que viviam à sombra da Falange Zona Norte estabelecem imediatamente um pacto com os 'vermelhos': a cadeia agora tem uma só liderança" (AMORIM, 2003:136). O episódio do confronto entre as falanges seria o momento da "insurreição dos saberes sujeitados", de acordo com as idéias de Michel Foucault". O Comando Vermelho controlava agora o "campo do poder" prisional da Ilha Grande. A experiência do "fundão" vai ser levada a todas as instituições penais. Surge o slogan da organização: "Paz, justiça e liberdade!".

Projetada para fora da Ilha Grande, a organização buscava estratégias de comunicação entre os presídios, articulando em rede um complicado sistema de mensagens conduzidas por familiares e advogados que visitavam a ilha. Essa missão ficaria a cargo do primeiro fugitivo após o massacre: Jorge Jordão de Araújo, o Caô-Caô (integrante da comissão inicial e um dos mais influentes "líderes vermelhos"). A Falange Vermelha construía seu "império" no núcleo insular, estendendo seu domínio territorial ao espaço prisional do Rio de Janeiro, formando uma poderosa rede criminosa que sustentava seu ordenamento territorial na ameaça da pena de morte para aqueles que não acatassem suas regras de conduta. Destarte, o surgimento da organização criminosa Comando Vermelho foi apontado pela primeira vez num relatório de 1979 , pelo então capitão da PM e ex-diretor do Presídio Cândido Mendes. Nélson Bastos Salmon:

O objetivo era chamar a atenção das autoridades penitenciárias para o risco que corriam no fortalecimento desses grupos (...) O alerta não foi assimilado, e além dessa organização, surgiram outras ao longo dos anos. $O$ relatório alertava também que o objetivo dessa quadrilha era o fortalecimento junto à massa carcerária, divulgando o poder diante das autoridades do governo, enfraquecendo as administrações do Sistema Penal para atingir o poder absoluto dentro das cadeias (PEREIRA, 1994:40-1).

A partir dos anos oitenta, com a fuga de vários presos do Comando

"Sobre os conflitos territoriais das falanges da Ilha Grande, o "Professor" conta alguns detalhes: "No dia marcado, com amplo apoio da coletividade, morreram de uma vez seis conhecidos quadrilheiros, os piores entre aqueles que mantinham o terror. Trinta deles se renderam, prometendo mudar o seu comportamento, e 20 pediram seguro de vida, sendo transferidos para Água Santa. A repercussão foi enorme, em todo o sistema. Em pouco tempo, as regras do antigo Fundão foram sendo adotadas nas cadeias: morte para quem assaltar ou estuprar companheiros; incompatibilidades trazidas da rua devem ser resolvidas na rua; violência apenas para fugir; luta permanente contra a repressão e os abusos. (...) As prisões ficaram mais calmas" (LIMA, 1991:76). 
Vermelho, "A Disciplina" seria adaptada às ruas. Formulada num manual de procedimentos, passava as instruções da organização para o bandido solto. Um manual básico serviria para evitar os erros primários cometidos pelo bandido despreparado $^{12}$. Em 1981, uma onda de assaltos a banco configura a preocupação crônica da polícia carioca, que tentava investigar esses assaltos relacionando-os às 109 tentativas de fuga ("trens") dos detentos do CV naquele ano. No vocabulário do crime, assalto vira "expropriação" ou "retomada"; quadrilha vira "coletivo". O bando foragido, liderado por William da Silva Lima, "o Professor", formou uma grandiosa quadrilha que se diferenciva pela "elegância" e "fineza" de seus assaltos. A quadrilha usava agora paletó, gravata e colete, fato que eliminava qualquer desconfiança dos agentes bancários e seguranças: era o "bando do cordão de ouro". Assaltaram inúmeras agências bancárias e joalherias. Mas, no final das contas, seus integrantes foram presos ou mortos pela polícia. De volta à Ilha Grande, um duro golpe na organização.

Após diversas fugas e uma experiência reterritorializadora no "mundo livre", 1981 é o ano do reencontro dos fugitivos do Comando Vermelho com o "Caldeirão do Diabo". A força da repressão empurra o Comando Vermelho de volta às celas e os foragidos recapturados são distribuídos pelas principais penitenciárias cariocas (Ilha Grande, Ari Franco, Esmeraldino Bandeira). Tentativa leviana das autoridades, pois a fama da organização já enorme e respeitada em todo o sistema carcerário; o número de adeptos do "coletivo" aumentou bastante, contando, no início de 1982 , com mais de 2.000 detentos $^{13}$. Em relação às falanges inimigas, elas também se fortaleceram. Alguns sobreviventes das falanges derrotadas em 1979 formam o Terceiro Comando.

Reorganizado, o "coletivo vermelho" terá uma nítida transformação ideológica: "O primeiro grupo era mais idealista, com laços de lealdade mais fortes. Agora as decisões são marcadas pelo pragmatismo e pela vontade de obter maiores

${ }^{12}$ As doze regras do "bom bandido" eram as seguintes: 1) Não delatar; 2) Não confiar em ninguém; 3) Sempre estar armado; 4) Lembrar-se sempre de que a polícia é organização, e nunca subestimála; 5) Respeitar mulher, criança e indefesos, mas abrir mão desse respeito quando a sua vida ou liberdade estiverem em jogo; 6) Estar sempre que possível documentado (mesmo com documento falso) e com dinheiro; 7) Não trazer consigo retratos, objetos com o nome gravado ou endereços suspeitos; 8) Andar sempre bem apresentável, com barba feita. Evitar falar gíria. Evitar andar a pé. Não frequientar lugares suspeitos. Não andar em companhia de "chave de cadeia"; 9) Saber dirigir autos, motos etc. Conhecer alguma coisa de arrombamento, falsificação e noções de enfermagem; 10) Lembrar-se sempre que roubar 100 ou 100 milhões resulta na mesma coisa (cadeia, condenação); 11) Estar sempre em contato com o criminalista; e 12) Não usar tatuagem em hipótese alguma.

${ }^{13}$ No lugar dos que estão mortos outros assumiram o poder da organização criminosa: Rogério Lengruber, o Bagulhão; José Carlos dos Reis Encina, o Escadinha; Paulo Cezar dos Reis Encina, o Paulo Maluco; José Carlos Gregório, o Gordo; Francisco Viriato de Oliveira, o Japonês - toda uma nova geração toma o lugar dos "companheiros caídos em combate". Neste momento (1982), William da Silva Lima e Carlos Alberto Mesquita, fundadores da Falange Vermelha, ainda são peças importantes dessa organização. 
lucros 'nos negócios'. É como se a organização deixasse de ser uma cooperativa (...) e passasse a ser uma empresa" (AMORIM, 2003:188). A definição da atividade principal da "companhia" é divergente entre as lideranças da falange. Há vários traficantes na nova direção e a opinião deles pesava bastante em relação ao investimento do tráfico. Os assaltos com fins corporativistas dariam lugar ao lucrativo tráfico de drogas, uma adaptação às novas exigências do mercado consumidor, e a droga dentro das celas era um rápido caminho para o controle de uma parte importante da massa carcerária.

Até 1980, o uso da cocaína era restrito a uma elite de usuários seletos e a venda de maconha era ainda do tipo artesanal. A relação PM-favela assumia contornos cada vez mais violentos com o Estado estruturalmente ausente, que só aparecia nas favelas nos periodos eleitorais. Os homens do Comando Vermelho (as lideranças das cadeias e os presos fugitivos) se aproveitaram do pretexto para aplicar nos morros sua expansão territorial com o código disciplinar. A conquista das favelas se fez com a disposição da organização em defender as comunidades carentes, uma vez que o Estado nada fazia por esse fosso da exclusão. O sentimento de revolta social foi explorado positivamente pelo $\mathrm{CV}$, estabelecendo uma "relação orgânica" com o povo da favela ${ }^{14}$.

Além disso, o Comando Vermelho vai se favorecer com a conjuntura social e política do Estado na eleição de Leonel Brizola ao governo, mito político convergente do populismo, renovado pela social-democracia na luta pelos direitos humanos. $O$ novo governo acenava com a proposta da eliminação dos castigos corporais, a desativação das "surdas" (celas de castigo), a vigilância sobre os procedimentos disciplinares para a eliminação do arbítrio, a assistência às famílias dos presos, a ampliação das oportunidades de trabalho nos presídios e penitenciárias e a regularização da condição jurídica da massa carcerária através da comissão especialmente designada. Em suma, criou-se dentro dos muros do sistema o mesmo clima de forte expectativa que o governo criara na sociedade externa: "Ora, todo e qualquer sistema prisional é extremamente sensível a estímulos externos" (COELHO, 1987: 108).

A humanização do sistema proibiu a polícia de subir as favelas para aterrorizá-las; procurou fazer valer a inviolabilidade do domicílio; obrigou as forças da lei a cumprirem mandados de busca; beneficiou os detentos dos presídios, dando-

\footnotetext{
${ }^{14}$ De acordo com Costa e Vieira (2004), a relação entre a organização "vermelha" e as favelas se torna quase idílica quando "(...) alguns sequiestradores ligados ao Comando Vermelho exigem que para além do valor do resgate, os familiares do refém deveriam distribuir, na favela do Jacarezinho, três caminhões de alimentos. Outros, após ter realizado um assalto a um banco na Zona Sul, organizavam grandes churrascos onde participavam a favela inteira. (...) Por sua parte as pessoas do morro mais necessitadas pediam para serem ajudadas na compra de remédios, tijolos, enterros etc. e eram sempre atendidas. Além disso, os homens do CV começaram a exercer uma intermediação em brigas ou negócios, relações com bicheiros etc." (p. 11).
} 
lhes o direito de se comunicar com advogados e familiares, evitando as torturas e os desaparecimentos. Na prática, o governo Brizola-PDT providenciou a abertura dos portões dos presídios e penitenciárias ao escrutínio da sociedade. A imprensa se beneficiou, devassando livremente o sombrio espaço prisional, jorrando para a leitura do cidadão os detalhes da sordidez das prisões cariocas. Os efeitos da moralização cultivaram um encontro histórico entre as autoridades públicas e os detentos da Ilha Grande:

A autoridade pública é recebida por um dos "vermelhos", um dos novos xerifes da prisão, Rogério Lengruber, o Bagulhão. $O$ representante do Comando Vermelho veste bermudas, sandálias havaianas e camiseta. Mete o medo na cara do secretário de Justiça e comunica a ele que os presos estão cansados de ouvir o blábláblá do governo. Esperam medidas concretas e imediatas. A visita ao "Caldeirão do Diabo" é cheia de incidentes. Os presos desfiam um rosário de críticas e reivindicações. William da Silva Lima faz um discurso de vinte minutos. (...) é aplaudido em delírio pelos presos (AMORIM, 2003:198).

O encontro entre as "autoridades" no "campo do poder" prisional alarmou o prelado do governo. Foi um incomensurável erro da parte governamental achar que homens como Bagulhão (Rogério Lengruber) não teriam representatividade entre a massa carcerária. O "coletivo" já dominava a cultura prisional e para corresponder à legitimidade da representação dos detentos foi criada, sob influência do Comando Vermelho, a Comissão Interna dos Direitos do Apenado (CIDA). Nesse período, a entidade alcançou êxito na maioria de suas exigências. A melhoria da vida dos detentos tornava-se clara com a quebra da incomunicabilidade do sistema, com a instalação de telefones públicos nos pátios e galerias dos presídios; a "visita íntima" foi instituída; a censura das correspondências foi suspensa; os presos passaram efetivamente a se alimentar melhor; os espancamentos cessaram como por encanto; a violência entre os presos praticamente desapareceu. Com isso, o "Comando Vermelho se fortaleceu a ponto de se tornar um poder inquestionável. Para a grande massa carcerária, aqueles eram benefícios obtidos pela organização - e não um favor do sistema" (AMORIM, 2003:204). O sentimento de impotência que afligia os presos, à consciência de que seu destino fluía ao sabor da vontade dos seus guardiões, chegava ao fim.

Mas, para além de toda subjetividade, as expectativas de mudança afetavam interesses sobre os quais assenta a precária ordem da prisão. Uma esfera de negociações e de compromissos tácitos que definem posições e privilégios na ordem social carcerária implicaria na contradição de uma "cumplicidade" entre o poder legítimo do Estado e o poder marginal dos presos. Nesse jogo territorial, cresciam os níveis de tensão e a exacerbação do conflito levaria a confrontos 
abertos de força, porque a prisão limita drasticamente o repertório de respostas adaptativas. Toda capacidade repressiva do sistema se mobilizou contra o Comando Vermelho, reforçando a percepção de que por trás de toda a retórica da "humanização" havia a coibição. O armistício do governo com o Comando Vermelho chegava ao fim: "Começaram imaginando a democratização das prisões, sem saber que o alicerce delas, a segurança e a disciplina, é implacavelmente autoritário. Não se democratiza o autoritarismo" (SOUZA, 2002:97).

Na Ilha Grande, as fugas persistiam. Em 1983, o governo revê a política adotada e isola as lideranças das facções criminosas num presídio de segurança máxima (Milton Dias Moreira, onde existia a Divisão Especial de Segurança). O processo desterritorializador ameaça o "coletivo". Porém, uma fuga inesperada acontece: Escadinha (José Carlos dos Reis Ensina), um dos líderes "vermelhos", escapa do cativeiro por um túnel cavado dentro da própria cela, deixando um boneco para representá-lo no confere da manhã. Outros 14 líderes do CV tentam a fuga, porém frustrada. Ao todo, a polícia conseguiu a proeza de ferir onze fugitivos e matar um deles. O resultado foi a volta de 33 "vermelhos" ao "paraíso" da Ilha Grande, iniciando uma terceira fase da organização.

A mudança de curso proposta pela administração penitenciária fez o Comando Vermelho rever suas atividades. Os veteranos do roubo armado, William da Silva Lima e Carlos Alberto Mesquita, perderam terreno nos assuntos internos da organização, embora continuassem respeitados pela massa carcerária. $\mathrm{Na}$ liderança dos “vermelhos" estão agora Rogério Lengruber (o Bagulhão), Francisco Viriato (o Japonês), os irmãos Encina (Escadinha e Paulo Maluco), Paulo César (o PC) e Gregório (o Gordo). A nova estratégia seria o controle do tráfico de drogas no Estado, um negócio mais seguro e rentável que os assaltos a banco, tendo como atividades paralelas o tráfico de armas de guerra e o roubo de automóveis. Nessa época, o tráfico de drogas já era disseminado numa escala global - a "União Corsa" na máfia francesa; a Máfia Siciliana na Itália; e a Cosa Nostra nos Estados Unidos. O Brasil era apenas uma das rotas da rede do narcotráfico internacional.

É neste contexto que os emissários do Cartel de Medellín de Pablo Escobar (considerado o maior traficante de entorpecentes do mundo) decidem colocar em prática no Rio de Janeiro a operação que ficou conhecida como o "Natal de neve". Escobar ofereceu ao mercado consumidor carioca uma cocaína super-refinada a preço de custo, de forma que a droga passou a ser consumida ostensivamente pelos jovens da classe média e das favelas. Conseqüentemente, os "coletivos" dos presídios fortaleciam a relação orgânica com os moradores das favelas, passando a investir parte de seus lucros em ações sociais nas comunidades pobres do Estado: "nas favelas ligadas ao tráfico, surgem os famosos postos médicos, creches, saneamento, condutas de água potável, galpões para os concertos de música funk, bem como as lojas e 'biroscas' que são abertas com a doação do chefe local do 
tráfico, inclusive igrejas evangélicas" (COSTA e VIEIRA, 2004:12).

Em 1986, na contabilidade do crime organizado, sessenta dos 98 grandes pontos-de-venda de maconha e cocaína já estavam dominados pelo Comando Vermelho, o que simbolizava a posse de diversos territórios para os "vermelhos", sendo as favelas do Vidigal, Rocinha, Dona Marta, São Carlos, além de outras favelas da Zona Norte, os nós da rede do narcotráfico. As ordens partiam dos presídios e chegavam aos bandos entrincheirados nas favelas. Os agenciamentos, controlados pelas redes da organização "vermelha", funcionavam à disposição dos líderes encarcerados no "Caldeirão do Diabo". O carisma dos líderes do CV seria importante para o comando da organização; era preciso o comando pessoal, fora das prisões. Novamente, só que agora de forma espetacular, Escadinha escapa de helicóptero da ilha-cárcere como numa cena de cinema ${ }^{15}$

Enquanto o CV dominava o crime organizado e o comércio de entorpecentes no Rio de Janeiro, expandindo sua territorialidade na conquista de novos pontos de venda, o ano de 1988 chegava para aterrorizar ainda mais a "sociedade dos cativos". O massacre recomeça e diversas vítimas são assassinadas friamente em todos os presídios - era o "cada dia morre um". O retorno de Rogério Lengruber, "comandante" do Comando Vermelho preso em Bangu I, para o presídio Cândido Mendes era reivindicado pelo "coletivo vermelho". Segundo Carlos Amorim (2003), a penitenciária de segurança máxima de Bangu I era um "muro de silêncio" em torno do Comando Vermelho devido à forte incomunicabilidade e isolamento de seus detentos. Foi para derrubar este "muro" que começou o "cada dia morre um", pois a "i-mobilidade" das lideranças da organização impunha-lhes uma forte desterritorialização:

A nova penitenciária, construída à força de alguns milhões de dólares, foi planejada para isolar completamente os líderes do crime organizado. Os muros têm oito metros de altura e são completamente lisos. As paredes das celas têm uma placa de ferro por dentro. Os telhados foram projetados para impedir o pouso de helicópteros - e ainda tem no centro um pequeno terraço com um ninho de metralhadora. Os visitantes e advogados não podem ter contato físico com os presos. Falam num parlatório igualzinho das cadeias do cinema: visita e preso, separados

\footnotetext{
${ }^{15}$ Era véspera de Ano-Novo, quando Escadinha estava acompanhado da visita de uma mulher: "De repente, saído do nada, um helicóptero Bell-47, made in USA, vem do mar e pousa aos pés do traficante. Escadinha e a mulher embarcam, sob olhares atônitos (ou cúmplices?) dos guardas (...). Decolam calmamente para desaparecer na direção do sol poente. Nunca se viu fuga mais fácil" (Amorim, 2003:233). Não houve o disparo de tiro algum e nenhuma voz se alterou. Escadinha vai parar no Morro do Juramento, onde a sua chegada foi comemorada com champanhe e tiroteios como fogos de artifício. Ele reassume os negócios da organização e a luta contra as facções rivais. "Para zombar ainda mais do poder público, Escadinha desfila numa escola de samba, durante o carnaval daquele ano. Sai de baiana, com direito a saia rodada e muito pó-de-arroz" (p. 234).
} 
por um vidro à prova de balas, se comunicam por telefone. Bangu Um foi construído para impedir qualquer tentativa de fuga. E até hoje, ninguém conseguiu escapar de lá. As celas do presídio de segurança máxima têm fechaduras eletrônicas. E um circuito interno de televisão vigia cada movimento. Como se tudo isso não bastasse, sensores fitoelétricos completam a segurança. É improvável alguém burlar - ao mesmo tempo - todos esses dispositivos. (...) Para ajudar o preso a se conformar com a cadeia, Bangu Um tem celas individuais, com banheiro. E são apenas doze celas em cada galeria. Tem sala de televisão e os presos vestem calças jeans e camisetas. Recebem roupa de cama, cobertor, creme dental e sabonete. A comida vem de uma empresa especializada em servir "quentinhas" (...). Para Bangu Um foram levados os 48 prisioneiros mais perigosos de todo o sistema carcerário, incluindo os trinta membros da comissão dirigente do Comando Vermelho. (...) No entanto, à medida que vão entrando em Bangu Um, os líderes simplesmente desaparecem. Não se comunicam mais, têm dificuldades para administrar os negócios das quadrilhas. "(Amorim, 2003: 313)".

Os fatos são claros ao se constatar que os "coletivos" do Comando Vermelho mantiveram a "administração" absoluta das cadeias, que os grupos armados continuavam agindo do lado de fora das prisões, que o controle do tráfico de drogas se ampliava e que o Comando Vermelho ainda possuía uma irrestrita hegemonia territorial no espaço prisional. Em janeiro de 1991, quando Brizola toma posse de seu segundo mandato como governador do Rio, as lideranças encarceradas procuraram restabelecer os canais de negociação, cessando repentinamente os seqüestros e a onda de violência. Com isso, as lideranças "vermelhas" conseguem ser transferidas de Bangu I para outros presídios. Porém, o lendário Rogério Lengruber, herói dos jovens "soldados" do Comando Vermelho, faleceu de insuficiência hepática e venosa, resultado de cirrose e diabetes. Com a morte de Bagulhão, Francisco Viriato de Oliveira, o Japonês, assumia o poder absoluto da facção criminosa; na hierarquia do crime, abaixo dele, estavam os irmãos Encina. Os chefes do tráfico de drogas ocuparam definitivamente o poder da organização.

As prisões são objetos históricos significativos quando nos mostram, no rigor de seus rituais, os limites que governam o exercício do poder. O poder não é uma propriedade do Estado, mas uma estratégia de ação; o poder não é atributo, mas relação de força que passa tanto pelos dominados quanto pelos dominantes, ambos constituindo singularidades. O significado de poder na análise foucaultiana é que ele produz a simetria, em vez de derivar apenas de uma superioridade; ele se exerce permanentemente, no lugar de se exercer de forma intermitente; ele se 
irradia de baixo para cima, sustentando as instâncias de autoridade legal; incentiva e faz produzir, ao invés de esmagar e confiscar. Mesmo diante da ruína do sistema penitenciário, sem vigilância estatal a ordem pública nas prisões ofusca-se. Um novo arranjo territorial se estabelece com o contraste entre o poder público promovido pelos sistemas penitenciários dos governos do Estado e Federal - e o poder da ação do crime organizado, donde sobressai o grupo mais forte, ou seja, o Comando Vermelho.

Bangu I, um presídio de "segurança máxima" construído para 48 presos, oferece dois exemplos de como a população teve notícia de que os presos comunicavam-se com o exterior. O primeiro caso é o do traficante Sérgio de Mendonça, o "Ratazana", que foi apontado pelo prefeito César Maia, em setembro de 1995, como o mentor de um plano para assassiná-lo. Inconformado com a acusação, o bandido enviou um fax diretamente de Bangu I, onde se encontrava preso, para a prefeitura, negando a existência do plano para matar o prefeito. César Maia protestou publicamente contra o uso do fax, mas nada aconteceu mediante a circunstância. Outro exemplo é mais recente: no dia 22 de janeiro de 2001, foi encontrado um túnel de $86 \mathrm{~m}$ de extensão e $1,70 \mathrm{~m}$ de altura, a $6 \mathrm{~m}$ de profundidade, iluminado e com sistemas de drenagem e refrigeração. Todo em concreto, o caminho, que começava em uma casa na Favela de Catiri, a $150 \mathrm{~m}$ do presídio, chegaria em linha reta até Bangu III e depois ligaria o presídio até Bangu I, que fica ao lado. Os dois casos citados mostram a rotineira comunicação dos presos com o mundo externo. Os efeitos das "máquinas cibernéticas" (computadores, fax, aparelhos de telefonia celular, etc.), que Gilles Deleuze tanto explorava, interferem cada vez mais nas relações entre o Dentro e o Fora das prisões cariocas. A nova tecnologia informacional promove fatos pertinentes à transformação pela qual passa o sistema penitenciário: a passagem da sociedade disciplinar à sociedade de controle. Essa transformação começou de forma lenta, mas hoje traduz toda a força da coletividade dos detentos, que agora se apresentam como sujeitos na medida em que escapam dos saberes e poderes dominadores, concebendo processos de subjetivação que, intensificados, modificam o ordenamento territorial do sistema prisional - linhas são quebradas, alterando o espaço-tempo.

A verdade é que o crime organizado se fortalece a cada dia e o poder da "narcoditadura" se estende cada vez mais com alianças tenebrosas. O Primeiro Comando da Capital (PCC), a facção criminosa que domina os presídios do estado de São Paulo, coliga-se ao maior grupo criminoso do Rio de Janeiro, o Comando

${ }^{16}$ A propósito, o item 16 do Estatuto do PCC afirma o seguinte: "O importante de tudo é que ninguém nos deterá nesta luta porque a semente do Comando se espalhou por todos os Sistemas Penitenciários (...). Em coligação com o Comando Vermelho - CV e PCC - iremos revolucionar o país dentro das prisões, e o nosso braço armado será o Terror "dos Poderosos" opressores e tiranos que usam o anexo de Taubaté e o Bangu I do Rio de Janeiro como instrumento de vingança da 
Vermelho, iniciando o ciclo das mega-rebeliões que se estenderam para outras partes do país. É importante frisarmos a questão da aliança entre essas poderosas facções do crime organizado ${ }^{16}$, pois foi no contexto dessa coligação que as múltiplas rebeliões do Rio de Janeiro aconteceram, sobretudo a de Bangu I. A crise penitenciária tornou-se mais aguda em 2002, quando o traficante Fernandinho BeiraMar (o novo "manda-chuva" do CV) chegou ao Rio transferido por decisão da Justiça. O plano do governo era impedir o contato do traficante com outros detentos, mas, de fato, o isolamento não aconteceu. A falta de condições de segurança nos presídios cariocas para acolher o traficante comprometeu irremediavelmente a credibilidade no sistema penitenciário. Usando o poder do dinheiro e da corrupção, Beira-Mar "conseguiu inverter a concepção arquitetônica prisional. Aproveitou o know-how do traficante colombiano Pablo Escobar, que construiu um presídio para ele mesmo ficar" (SOUZA, 2002:179).

No ano de 2002, onze incidentes prisionais, dentre algumas fugas, foram efetivadas no complexo de Bangu (todas em prisões dominadas pelo Comando Vermelho com a autoridade de Beira-Mar). Além disso, o assassinato brutal do jornalista Tim Lopes, da rede Globo de TV, repercutiu na opinião pública e nas autoridades governamentais ${ }^{17}$

$\mathrm{Na}$ cerimônia do segundo aniversário do Plano Nacional de Segurança Pública, o presidente Fernando Henrique Cardoso elevou o crime organizado à condição de "inimigo $\mathrm{n}^{\mathrm{o}} 1$ " do país, anunciando que o combate à violência era a prioridade máxima na agenda nacional ${ }^{18}$.

No momento em que o governo buscava solucionar os problemas relacionados ao crime organizado, tentando adaptar-se à nova realidade, a penitenciária de Bangu I, afamada por nunca ter sofrido fugas ou motins de presos, será o alvo das atenções da mídia e da sociedade pela proporção da mega-rebelião ocorrida em 11 de setembro de 2002. Planejada por Beira-Mar, a famosa rebelião aconteceu exatamente um ano após o atentado terrorista às torres gêmeas do World Trade Center, em Nova York (EUA). Enquanto o mundo assistia pela televisão à cerimônia que marcava um ano do atentado de Osama bin Laden (chefe da poderosa Al-Qaeda), Beira-Mar fazia a sua trama, escolhendo simbolicamente a mesma data para a rebelião por ele esquematizada. $O$ impacto da rebelião seria monstruoso, uma vez que o luto de Nova York estava no ar em todas as televisões do mundo.

sociedade, na fabricação de monstros. Conhecemos a nossa força e a força de nossos inimigos. Poderosos, mas estamos preparados, unidos e um povo unido jamais será vencido. (...) LIBERDADE! JUSTIÇA! E PAZ!!! (...) O Quartel General do PCC, Primeiro Comando da Capital, em coligação com o Comando Vermelho CV. Unidos venceremos" (AMORIM, 2003:390).

${ }^{17}$ Sobre o caso Tim Lopes, ler Souza (2002).

18 "FH: Crime organizado é inimigo número 1 do país": $O$ Globo, caderno Rio, 21/06/2002, p.15.

${ }^{17}$ Sobre o caso Tim Lopes, ler Souza (2002).

18 "FH: Crime organizado é inimigo número 1 do país": $O$ Globo, caderno Rio, 21/06/2002, p.15. 
De repente, naquela manhã, as emissoras brasileiras começaram a tratar de um outro assunto; foi um dos momentos mais significativos da luta entre as facções que controlam o tráfico de drogas no Rio de Janeiro.

Após um "confere" rotineiro na galeria A, na manhã de 11 de setembro, em Bangu I, onde estavam presos os líderes do comando Vermelho - dentre eles, Fernandinho Beira-Mar; Márcio dos Santos Nepomuceno, o Marcinho VP (o "poderoso" do Complexo do Alemão); Marcos Marinho dos Santos, o Chapolin (pessoa muito próxima de Beira-Mar) e um grupo de outros doze ligados à organização "vermelha", colocaram em prática a ação programada: renderam, com duas pistolas $9 \mathrm{~mm}$, uma 380 e outra 7.65 , além de dois revólveres e três granadas, os dois agentes penitenciários (desarmados) responsáveis pelo "confere", invadindo, logo após, uma sala da administração da cadeia, dominando mais seis reféns e tomando mais um rifle calibre 12 . Os amotinados abriram de imediato as portas da galeria $\mathrm{C}$, onde estavam os demais integrantes da facção "vermelha". As chaves foram divididas e as armas distribuídas. Já eram, em número, mais de trinta, e o objetivo circunstancial era matar seus desafetos das facções rivais (Terceiro Comando e Amigos dos Amigos) que ficavam presos na galeria D. Quando a porta da galeria foi aberta, os "vermelhos" começaram a abrir fogo contra seus inimigos; quatro morreram e três ficaram feridos.

Os alvos prioritários do ataque eram, simbolicamente conforme o atentado de Nova York, as "duas torres" a serem derrubadas: Ernaldo Pinto de Medeiros, o Uê, considerado o maior traidor do Comando Vermelho, e Celsinho da Vila Vintém. O massacre não seria apenas uma vingança ou um simples desejo de dominar o tráfico de drogas, mas um acerto de contas. Havia um plano por parte do grupo ligado ao traficante Uê para exterminar rivais do Comando Vermelho. Os guardas de Bangu I teriam sido, portanto, inicialmente subornados por Uê. Porém, um desses guardas passou essas informações para Fernandinho Beira-Mar, que pagou mais pelo plano a ser executado, comprando as chaves da cadeia.

Quando os "vermelhos" andavam armados no pátio do presídio em direção à porta, um grupo de agentes do SOE (Serviço de Operações Externas) os surpreendeu. Houve troca de tiros e os detentos recuaram para dentro do prédio. Teria sido, então, o momento em que foram eliminados os adversários do Terceiro Comando e da AdA. Oito reféns serviram de cordão de isolamento contra o avanço da tropa de choque da Polícia Militar, que já se preparava pra invadir o presídio.

\footnotetext{
${ }^{19}$ Nas palavras de Percival de Souza (2002:180), "os escolhidos pressentem, sabem que chegou a hora quando os matadores vão se aproximando, armados, ódio escrito nos olhos. Pode-se xingar, no máximo, recebendo golpes e golpes, tiros e tiros, urrando de dor que faz o prazer dos assassinos. O corpo de Uê, propositalmente deixado com um resto de vida, foi envolto em colchões e cobertores, e logo consumido pelas chamas. Deixou no ar e nas paredes, por longa distância, o cheiro da carne humana. Os traficantes mais perigosos do Rio de Janeiro gostam de matar, cremar, calcinar, reduzir a cinzas, transformar em pó branco. O corpo de Uê ficou assim: um monte disforme de cinzas".
} 
Bateram o primeiro sinal: "Se houver invasão, explodiremos tudo!". A hierarquia e a disciplina, que já tinham sucumbido, ficaram sepultadas de vez. Os assassinos foram consumados a tiros e a golpes de punhal ${ }^{19}$. Um novo grito de ordem foi evidente: "Ninguém entra enquanto o serviço não estiver feito!", avisou Fernandinho Beira-Mar. Do lado de fora dos muros da penitenciária Bangu I, cerca de 500 soldados da Polícia Militar e do Batalhão de Operações Especiais aguardavam o desfecho da rebelião, que na realidade trata-se de um "acerto de contas" com quatro traficantes mortos. Depois das execuções, uma escuta telefônica interceptou a conversa de Beira-Mar com um amigo. Repetindo a letra de um funk de sucesso, mostrou a força de sua territorialidade: "Tá dominado, está tudo dominado. As duas torres caíram". Na conversa - em que eram perceptíveis os ruídos de gritos e o som do motim -, Beira-Mar preocupou-se em saber da repercussão da revolta. Alertado por Celsinho da Vila Vintém (um dos líderes da facção Amigos dos Amigos), Beira-Mar se antecipou aos rivais. Celsinho, até então parceiro de Uê e inimigo do Comando Vermelho, foi poupado, embora estivesse acuado a todo momento da rebelião com uma faca em seu pescoço.

Terminado o "serviço", Beira-Mar libertou os reféns depois de entregar às autoridades uma carta com reivindicações. A demonstração de poder do traficante gerou indignação, mostrando a falência do sistema prisional. Pelos celulares, que conseguem sem dificuldade, os bandidos negociam a distribuição de drogas nas favelas, compram armamentos e ordenam a morte de inimigos. Os celulares são utilizados para minimizar a saudade de mulheres, filhos e amigos. Diferentemente do que acontecia há alguns anos, hoje a maioria das rebeliões não surge como protesto de presos revoltados com a precariedade da comida e das condições na cela, são tumultos organizados por líderes de quadrilhas, movidos por interesses como eliminar concorrentes ou serem transferidos para cadeias nas quais seja possível operar com mais liberdade.

Com o fim da mega-rebelião de Bangu I, Beira-Mar foi transferido para fora do Rio. O caso foi envolvido numa grande negociação interestadual que durou alguns meses: primeiro ficou preso junto à Polícia Federal em Brasília, depois foi transferido para uma cadeia federal em Maceió, e, por fim, ficou completamente desterritorializado no presídio de segurança máxima de Presidente Prudente, no interior do Estado de São Paulo. Já Márcio Amaro de Oliveira, o Marcinho VP, que ganhou as manchetes dos jornais em 1996 quando negociou com o cineasta Spike Lee a gravação de um clipe do popstar Michael Jackson neste morro, além de estar sendo mal visto pelos integrantes da facção por causa das declarações que deu ao jornalista Caco Barcellos, autor do livro "Abusado" (Record, 2003), foi encontrado morto em Bangu III, provavelmente por asfixia, e seu corpo foi localizado dentro de uma lixeira do presídio.

$\mathrm{O}$ drama de 11 de setembro rendeu inúmeros diagnósticos e reflexões sobre a segurança pública. Porém, nem a melhor segurança arquitetônica funciona 
quando a corrupção e a imoralidade corrompem os muros da sociedade dos territórios cativos. No Rio de Janeiro, a distribuição dos detentos criminais nas prisões é feita pela separação das facções rivais do crime organizado. Quando um criminoso é preso ou condenado no Rio de Janeiro, chega o momento de decidir para que cadeia ele será mandado. Quem imagina que os critérios para essa escolha são coisas como vagas disponíveis nos presídios ou periculosidade do bandido, não está a par das verdadeiras leis do sistema carcerário. O criminoso é encaminhado pelos funcionários do sistema para a cadeia dominada pela facção à qual pertence, isto é, toma-se sempre o cuidado de enviar o bandido para o aconchego da sua gangue. Este procedimento tolerante é conhecido como a "fórmula da paz". A desterritorialização sobre os detentos, que deveria ser promovida pelo próprio Estado, não acontece de fato. Com a máquina disciplinar falida, acuada sob a intervenção violenta do crime organizado, os detentos reagem por estarem re-territorializados nas cadeias.

A "fórmula da paz" nos cárceres cariocas está na ponta da língua de qualquer agente penitenciário. Nas fichas dos presos no Departamento do Sistema Penitenciário (Desipe) consta o nome do grupo ao qual cada condenado "pode" pertencer: Comando Vermelho, Terceiro Comando, Amigo dos Amigos (AdA), Comando Vermelho Jovem ou Terceiro Comando Jovem. O loteamento da cadeia é feito de forma irregular e ilegal. Os presídios são "rachados" entre as cinco principais facções criminosas do Estado, porque o Comando Vermelho "tem" mais cadeias, por ser mais organizado e possuir cerca de $1 / 3$ da população carcerária. $O$ restante da porcentagem está dividido entre as outras facções criminosas. Por exemplo: um bandido é apanhado pela polícia e vai ser preso. Antes de tudo, pergunta-se a ele a que comando pertence. Supondo que seja o Comando Vermelho, abre-se de imediato um cardápio pré-definido: presídios Bangu III, Bangu IV e Vicente Piragibe; penitenciária Edgar Costa (semi-aberta); e duas casas de custódia (onde o preso é mantido enquanto aguarda julgamento). Chova ou faça sol, essas seis unidades do sistema penitenciário são reservadas ao Comando Vermelho. Na federação carcerária do crime, a penitenciária Lemos de Brito, o presídio de Bangu II e a unidade semi-aberta Plácido Sá Carvalho são territórios exclusivos da facção Terceiro Comando. Existem também as prisões "neutras", teoricamente sem facção, como o presídio Hélio Gomes.

Já o surgimento da facção Amigos dos Amigos foi um fato decisivo para a situação de equilíbrio e de auto-neutralização da federação carcerária (considerando-se que as alas jovens do Comando Vermelho e do Terceiro Comando convivem bem com seus precursores). A AdA surgiu como uma espécie de dissidência das duas grandes facções rivais, e se impôs na denominada federação por sua capacidade de negociar com os poderes oficiais. Embora seja o menor dos* comandos criminosos, a jovem facção tem um presídio só para si: o Milton Dias Moreira. A distribuição das cadeias entre as facções criminosas não é uma mera 
concessão ao crime; é um artifício usado pelas autoridades penitenciárias para tentar cumprir sua obrigação de garantir a integridade física dos presos. A mistura generalizada dos comandos geraria uma carnificina permanente atrás das grades. Mas, acima de tudo, a estratégia da "fórmula da paz" aplica o princípio maquiavélico de dividir para governar. É o que mina um movimento articulado, como é o caso das cadeias paulistas, onde a facção criminosa Primeiro Comando da Capital (PCC) monopoliza o "campo do poder".

Atualmente, com a política da "fórmula da paz", não há no estado do Rio de Janeiro prisão que misture facções criminosas. As prisões cariocas são "neutras" ou são compostas por detentos ligados a uma facção do crime, discriminadas pelo Desipe para não haver um conflito maior (como foi o caso das rebeliões com inúmeras chacinas de Bangu I, em 2002, e de Benfica, em 2004). Encarcerado num Distrito Policial (DP), o preso fichado inicia a sua admissão no sistema penitenciário, caso não consiga anular a sua condenação. A distribuição dos presos é feita pelo Desipe, órgão descentralizado e relativamente autônomo da Secretaria de Justiça, que aprisiona o sujeito intimado numa Casa de Custódia até o período de um mês (data limite para a consumação de sua sentença). Neste momento, o preso passa por uma rigorosa disciplina: pouca ou nenhuma segurança, sem direito a tomar banho e sem visitas. Assimilado o processo de "prisonização"20, o detento é transportado para um dos presídios pela SOE (Setor de Operações Especiais) de acordo com a facção criminosa filiada ou por sua "neutralidade", com o artigo que o condenou, com o tempo de sua punição, também sendo caracterizadas as tatuagens e as cicatrizes de seu corpo. Perdendo a identidade pessoal ao presidir uma instituição carcerária, o "calouro-preso" ainda é "cadastrado" pelos próprios detentos, que varia em sua modalidade de prisão em prisão. Em alguns presídios existe a "Triagem", uma espécie de cárcere de adaptação, quando o preso chega na "leva" de sexta-feira, ficando nesta cela por aproximadamente quatro dias. $\mathrm{Na}$ linguagem dos agentes penitenciários, a "Triagem" convém para a "aclimatação" do detento na instituição. No caso do Presídio Esmeraldino Bandeira (Terceiro Comando), a porta gradeada da "Triagem" fica a poucos metros de um pavilhão ou galeria, onde o exercício da comunicação dos internos já estabelecidos com os "calouros" serve para saber quem entrou no presídio. Pergunta-se quem ele é, de onde veio, se tem algum desafeto e o que fez para estar lá. Caso o "calouro" não sinta garantias futuras, é o momento certo para pedir o "seguro" em outra instituição; se concordar com as normas instituídas pelos presos, estará pronto para ser acolhido.

A princípio, os presídios dominados pelo Terceiro Comando não se organizam em forma de "coletivo", como acontece nos territórios "vermelhos", propiciando a "Lei de Muricî" (a lei do "cada um por si”), a mais comum em seus

${ }^{20}$ Sobre os efeitos da "prisonização" (processos de mortificação prisional), veja o conceito em Goffman (1974) e Thompson (1980). 
domínios. Já no Presídio Muniz Sodré, território do Comando Vermelho, não existe a denominada "Triagem", pois o detento já fora cadastrado previamente pelo Desipe como sendo da facção vermelha. A chegada do detento nesta instituição é marcada por uma espécie de cadastro com o "coletivo", com nome, área de atuação na sociedade livre ("boca") e seu vulgo (apelido). É formado um tipo de interrogatório formal entre a "federação" (ou "grupo") com o "calouro" para a sua aceitação na instituição, onde é passada a concordância para todos os detentos do presídio na ordem do grito de "circulou geral", que no linguajar dos presos, significa "reunião".

Nos presídios do Comando Vermelho, a "Federação" (ou "Grupo") forma o "coletivo", que é altamente agenciado pela organização criminosa dentro e fora do território prisional, conduzido por normas severas ditadas na forma dos "dez mandamentos" (não roubar, não praticar a pederastia, não delatar, etc.) pelo lendário "marechal" Rogério Lengruber. Existe uma forte hierarquia em sua organização. No topo das categorias do "coletivo" estão os "Amigos da Federação", sendo estes os responsáveis pela gerência, pelo bem estar e pelo juízo de todos os indivíduos confederados e não confederados. O "coletivo" é organizado pelos próprios presos, formando uma forte resistência às normas institucionais. Quando acontece algum problema grave que envolve o interesse do Diretor do presídio, é aos "Amigos da Federação" que ele se dirige, fazendo acordos mútuos para abafar os conflitos. Seguindo a hierarquia do "coletivo", está o "responsável da cela", que tem a função imediata de garantir a boa funcionalidade da cela no aspecto de mando local. Qualquer problema ou intriga dentro de uma cela deve ser transmitido ao "responsável da cela", pois ele será o juiz do conflito. Ele também faz a reclamação e a devolução do "alaô" (comida; "rango") estragado através do "ligação de cela". Normalmente, quando um preso é julgado culpado por algum fato, seja por que roubou, bateu, falou mal ou brincou com a sexualidade de alguém (na prisão o indivíduo tem que ser "sujeito homem"), o "responsável da cela" manda chamar os detentos da área (bairro, favela ou morro) do acusado para disciplinar de acordo com as normas do "coletivo". Segundo o pensamento da "Federação", não deve haver "vacilação" na hora da punição, sendo os algozes do acusado as pessoas ligadas à sua própria área de atuação, aplicando-lhe uma penalidade.

O "coletivo" configura a estrutura de redes no território prisional do Comando Vermelho. Funciona constantemente em fluxo para fazer a comunicação e a interceptação de objetos entre os presos em meio às celas, às galerias e à sociedade livre. Qualquer informação transmitida ou qualquer objeto passado é anotado nos mapas do "ligação" (receptor), que chega a ele sempre através do "toque", uma espécie de folha de papel com o cabeçalho do Comando Vermelho (CV - RL) e os códigos, comunicando o que lhe está sendo transmitido ou passado, de quem e para quem é, de onde veio (vulgo, cela tal, galeria tal), desde a sua origem, que cruza "ligação" com "ligação", até o seu destino (os mapas e os "toques" são como bilhetes cifrados). O "toque" não pode ser anotado na cor 
vermelha, o que significa nos códigos da prisão a guerra. Existe uma hierarquia da "ligação", delimitada por escalas e áreas do presídio, com direito à promoção dos "soldados" do Comando Vermelho quanto à elevação de cargo: "ligação de cela", "ligação da pista" (galeria), "ligação da cortina" (entre as grades que separam as celas), "ligação da cantina" (responsável pelas compras na cantina) e, finalmente, "ligação central" (que faz a "última forma na ligação geral").

Os "ligações" são vigiados por outros prisioneiros chamados "monitores", os homens de destaque do "coletivo", cuja tarefa é a de verificar o desempenho dos "ligações" (existe um tipo de "monitor" para cada tipo de "ligação"). O "ligação" deve completar sua tarefa especificada no "toque"; caso isso não ocorra, ele é o responsável pelo prejuízo e "deve morrer com a roupa" (expressão usada na cadeia), que significa pagar o estrago com seus próprios recursos ou com sua integridade física (dependendo da situação). Quando a venda de um produto é completada por um "ligação", "abalô" é o termo usado. De noite, quando a prisão está trancada e apagada, é o melhor momento para fluirem as informações e para se transmitir o que se quer pelos "toques", que são passados de cela em cela, de "ligação" em "ligação" até "abalar". Os "toques" com as informações a serem transmitidas e os objetos a serem passados atravessam lugares estratégicos que conectam as celas: pequenos buracos ("cachoeira") que os detentos fazem na parede das celas, interligando o espaço que as separa caso as celas sejam vizinhas de lado; jogando para frente das celas os objetos e o "toque", de grade em grade, caso as celas sejam vizinhas de frente; e pelo "boi" (buraco da privada do banheiro) que tenha ligação com o "boi" de outra cela.

O "coletivo" é a forma de organização encontrada nos presídios do Comando Vermelho. A expressão "coletivo", constituída pela Falange Vermelha nos tempos da extinta "Ilha Grande", sofreu grandes mudanças estruturais, mas ainda serve aos detentos como fórmula de união e força nas unidades prisionais contra o sistema carcerário. Sem dúvida, todos os problemas enfrentados na vida cativa proporcionam a organização de outras normas nas instituições, feitas pelos próprios detentos, concorrendo paralelamente (e muitas vezes se entrecruzando) com as normas legais e ilegais promovidas pelo sistema prisional. $O$ confinamento e o regime de vigilância/controle ao qual está submetido o interno estimula-o a arquitetar uma infinidade de fórmulas para burlar os "regulamentos oficiais" da prisão. Parafraseando Foucault, o "coletivo" foi o principal artifício da "insurreição dos saberes sujeitados" contra as enfermidades do sistema prisional brasileiro.

Resumo: Este artigo analisa o ordenamento territorial configurado pelo "coletivo" dos detentos nos presídios e penitenciárias do Estado do Rio de Janeiro. Nossa proposta vem incorporar-se ao conjunto de estudos brasileiros sobre a pena privativa de liberdade e sobre as funções reais e simbólicas por ela desempenhadas. Sob a orientação da Geografia crítica e de um conjunto de tendências interdisciplinares, no bojo da "criminologia crítica", 
examinamos o "coletivo" como estratégia de ação territorial dos presos, ampliando a discussão sobre a luta do poder político nas prisões e valorizando o papel do domínio dos territórios e das territorialidades referentes ao espaço prisional. Nosso testemunho sobre o "coletivo" se ampara nas considerações conceituais do território e da territorialidade e seus vínculos com as relações de poder, observando as implicações que a formação territorial do "coletivo" institui na "sociedade dos cativos", bem como nas particularidades político-jurídicas e sócio-culturais que envolvem o poder, a disciplina, a vigilância, os saberes e o controle, além das alusões desdobradas, contraditórias e supervalorizadas do sistema prisional.

Palavras-chave:: território; territorialidade; poder.

\section{THE "COLLECTIVE" AS TERRITORIAL STRATEGY OF THE CAPTIVES}

Abstract: This article analyses the territorial organization shaped by the "collective" of the detainees in prisons of the State of Rio de Janeiro, Brazil. Our proposal comes to be incorporated to the set of Brazilian studies on the private feather of freedom and to the real and symbolic functions that are fulfilled by it. Under the approach of Critical Geography and a set of interdisciplinary tendencies in the area of "critical criminology", we examine the "collective" like strategy of territorial action of the prisoners, enlarging the discussion on the struggle of the political power in prisons and valuing its role, concerning to territories and territorialities referring to the prison space. Our testimony about the "collective" is supported by conceptual considerations about territory and territoriality and its bonds with the power relations, observing the implications that territorial formation of the "collective" establishes in the "society of the captives", in the legal-political and socio-cultural specificities that wrap power, discipline, vigilance, knowledge and control, besides the unfolded, contradictory and supervalued allusions of the prison system.

Key-words: territory; territoriality; power.

\section{BIBLIOGRAFIA}

AMORIM, Carlos. 2003. CV-PCC: A irmandade do crime. Rio de Janeiro: Record. BAUMAN, Zygmunt. 2001. Modernidade Liquida. Rio de Janeiro: Jorge Zahar. CAPEL, Horacio; FRAILE, Pedro; SANCHEZ, Joan-Eugeni; et alli. (orgs.) 1990. Los espacios acotados: Geografia y dominación social. Barcelona: PPU.

COELHO, Edmundo Campos. 1987. A oficina do diabo: Crise e conflitos no Sistema Penitenciário do Rio de Janeiro. Rio de Janeiro: Espaço \& Tempo - IUPERJ.

COSTA, André Saldanha e VIEIRA, Thiago Braga. 2004. Comando Vermelho: Da solidariedade de "A Disciplina" à barbárie da guerra do tráfico. Revista Nação Brasil, ano 7, no. 143, jun. Rio de Janeiro: ADIA.

DELEUZE, Gilles. 1992. Conversações. 1972-1990. São Paulo: Ed. 34. FOUCAULT, Michel. 1996. A verdade e as formas jurídicas. Rio de Janeiro: NAU. 2003. Estratégia, poder-saber. Rio de Janeiro: Forense Universitária. 
. 1998. Microfísica do poder. Rio de Janeiro: Graal.

FRAILE, Pedro. 1990. "Lograr obediencias maquinales". Un proyecto espacial. In: CAPEL, Horacio.(org.). Los espacios acotados: Geografia y dominación social. Barcelona: PPU.

GOFFMAN, Erving. 1974. Manicômios, prisões e conventos. São Paulo: Perspectiva.

HAESBAERT, Rogério. 1997. Des-territorialização e identidade: A rede "gaúcha" no Nordeste. Niterói: EDUFF.

. 2004. O mito da desterritorialização: Do "fim dos territórios" à multiterritorialidade. Rio de Janeiro: Bertrand Brasil. 2002. Territórios alternativos. São Paulo: Contexto.

HARDT, Michael. 2000. A sociedade Mundial de Controle. In: ALLIEZ, Eric (org.). Gilles Deleuze: Uma Vida Filosófica, São Paulo: Ed. 34.

LIMA, William da Silva. 1991. Quatrocentos contra um: Uma história do Comando Vermelho. Petrópolis: Vozes.

PEREIRA, Inair de Souza. 1994. História da penitenciária Cândido Mendes. s.n. RAFFESTIN, Claude. 1993. Por uma geografia do poder. São Paulo: Ática.

SACK, Robert David. 1986. Human territory: Theory under history. Cambridge: University Press.

SÁNCHEZ, Joan-Eugeni. 1990. Poder y apropriación del espacio. In. CAPEL, Horacio (org.). Los espacios acotados: Geografia y dominación social. Barcelona: PPU.

SOUZA, Marcelo J. L. 1995. O território: Sobre espaço, poder, autonomia e desenvolvimento. In:

CASTRO, I.. et alli (orgs.). Geografia: Conceitos e temas. Rio de Janeiro: Bertrand Brasil.

SOUZA, Percival de. 2002. Narcoditadura: O caso Tim Lopes, crime organizado e jornalismo investigativo no Brasil. São Paulo: Labortexto Editorial.

SYKES, Gresham M.1972. The society of captives. New Jersey: Princeton University Press.

THOMPSON, Augusto. 1980. A questão penitenciária. Rio de Janeiro: Forense. WACQUANT, Loïc. 2001. As prisões da miséria. Rio de Janeiro: Jorge Zahar. 